James D. G. Dunn

\title{
The New Perspective on Paul
}

\section{Collected Essays}

[Die Neue Paulusperspektive. Gesammelte Aufsätze.]

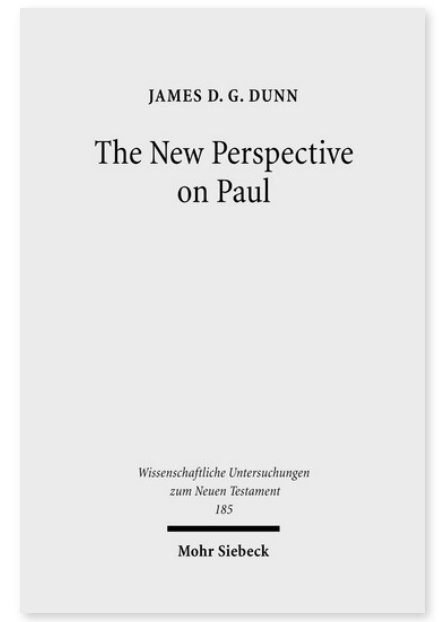

2005; unrevised paperback edition; 2007. XII, 539 Seiten. WUNT I 185

ISBN 978-3-16-151488-3

DOI 10.1628/978-3-16-151488-3

eBook PDF 109,00 €

ISBN 978-3-16-149518-2

fadengeheftete Broschur 109,00€
Veröffentlicht auf Englisch.

Diese Essays heben eine bisher vernachlässigte Dimension der Theologie des Paulus hervor: Seine Lehre entstand als integraler Bestandteil seines Verständnisses als jemand, der das Evangelium den Nicht-Juden predigte. Seine Ablehnung der Rechtfertigung durch »Werke des Gesetzes« war weniger gegen den jüdischen »Legalismus« als vielmehr gegen die jüdische Annahme gerichtet, daß das Gesetz christliche Juden und christliche Heiden trenne. Der lange Einführungsessay beschäftigt sich mit dieser neuen Paulusperspektive und versucht, die Debatte über die jüdische Soteriologie, über die Beziehung zwischen Rechtfertigung durch Glauben und Beurteilung gemäß den Werken und über die entscheidende Rolle von Christus, seines Todes und der Wiederauferstehung neu zu beleben.

James D. G. Dunn (1939-2020) Emeritus Lightfoot Professor of Divinity, University of Durham.

Jetzt bestellen:

https://mohrsiebeck.com/buch/the-new-perspective-on-paul-9783161514883?no_cache=1

order@mohrsiebeck.com

Telefon: +49 (0)7071-923-17

Telefax: +49 (0)7071-51104 